\title{
Use of hybrid approach in facilitation of design of ship hydrostatic parameters under uncertainty
}

Thaddeus C. NWAOHA, Fabian I. IDUBOR

DOI: 10.30464/jmee.2019.3.1.31

Cite this article as:

Nwaoha T. C., Idubor F. I. Use of hybrid approach in facilitation of design of ship hydrostatic parameters under uncertainty. Journal of Mechanical and Energy Engineering, Vol. 3(43), No. 1, 2019, pp. 31-42.

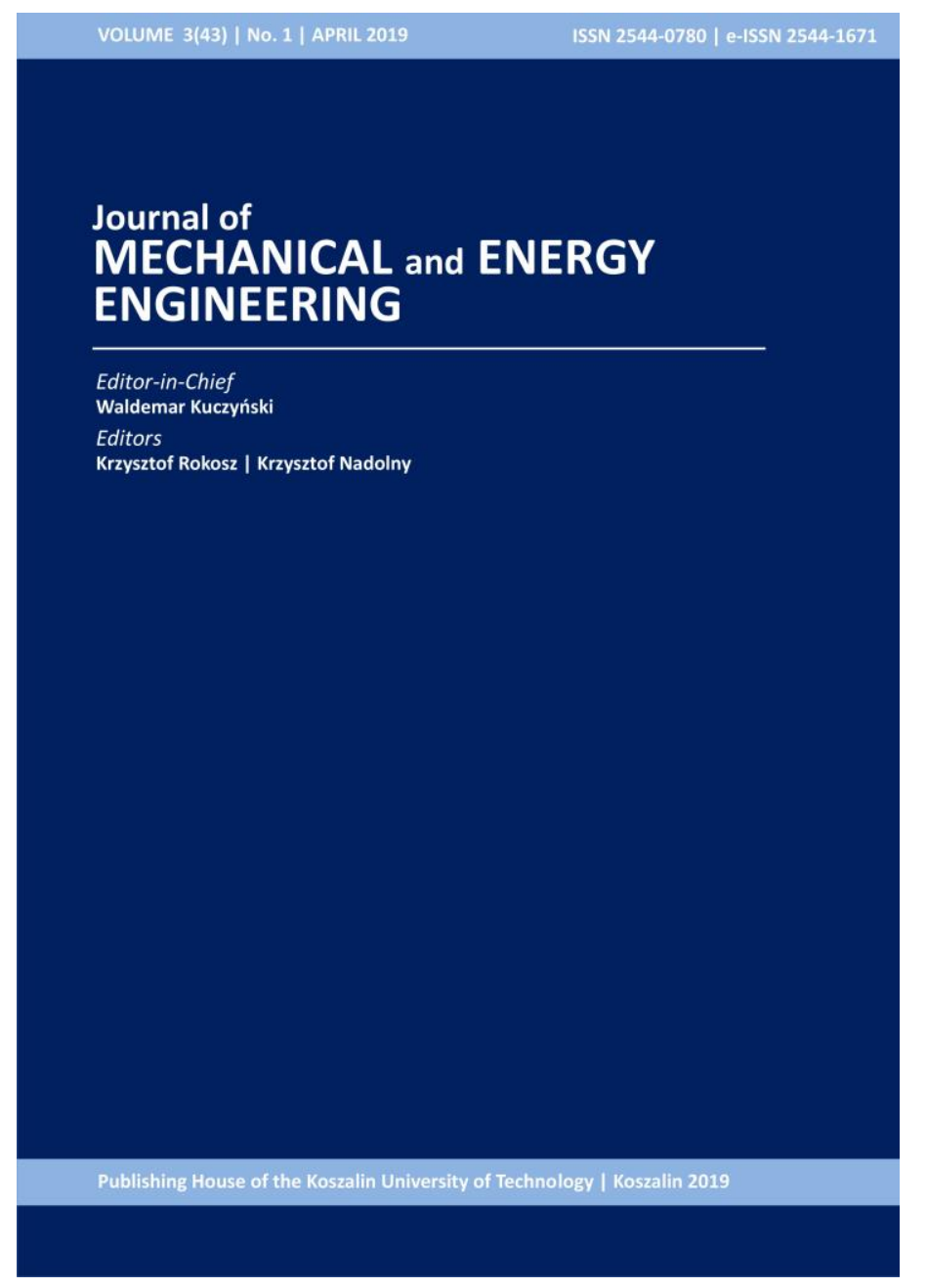

Journal of Mechanical and Energy
Engineering

Website: jmee.tu.koszalin.pl

ISSN (Print): 2544-0780

ISSN (Online): 2544-1671

Volume: 3(43)

Number: 1

Year: 2019

Pages: 31-42

\section{Article Info:}

Received 25 February 2019

Accepted 18 March 2019

\section{Open Access}

This article is distributed under the terms of the Creative Commons Attribution 4.0 (CC BY 4.0) International License (http://creativecommons.org/licenses/by/4.0/), which permits unrestricted use, distribution, and reproduction in any medium, provided you give appropriate credit to the original author(s) and the source, provide a link to the Creative Commons license, and indicate if changes were made. 


\title{
USE OF HYBRID APPROACH IN FACILITATION OF DESIGN OF SHIP HYDROSTATIC PARAMETERS UNDER UNCERTAINTY
}

\author{
Thaddeus C. NWAOHA ${ }^{1 *}$, Fabian I. IDUBOR ${ }^{1}$ \\ ${ }^{1}$ Department of Marine Engineering, Federal University of Petroleum Resources, Delta State, Nigeria, \\ e-mail: nwaoha.thaddeus@fupre.edu.ng
}

(Received 25 February 2019, Accepted 18 March 2019)

\begin{abstract}
Hydrostatic parameters of a ship are very important in ship design. The importance of the parameters compared to one another need to be revealed in realm of uncertainty, so as to avoid design error. In view of this, a fuzzy-analytical hierarchical process (Fuzzy-AHP) method is utilized in addressing the subject under investigation. The fuzzy logic is used to address uncertainty in pairwise comparison exercise, so as to facilitate the estimation of order of importance of hydrostatic parameters. In this research, the engineering judgements of three designers in analysis of importance of hydrostatic parameters are aggregated and processed using the Fuzzy-AHP methodology. The result produced in the study showed that hydrostatic parameters are importance in order of moments of inertia of vessels (MIV), mass displacement (MD), tons per centimeter immersion (TPCI), coefficients of form (CF), centers of buoyancy (CB), metacentric heights of vessels (MHV), ship waterplane area (SWA), longitudinal center of floatation (LCF), volume displacement (VD) and wetted surface area (WSA) with weight values of $0.218,0.095,0.078,0.083,0.074,0.1,0.46,0.108,0.209$ and 0.028 respectively.
\end{abstract}

Keywords: Hydrostatic parameters, Fuzzy logic, AHP, Ship, Uncertainty, Comparison

\section{INTRODUCTION}

Ship stability in water is one of the basic challenges Marine Engineers and Naval Architects face during ship design, construction and operation at sea. Based on this fact, it is imperative that ship hydrostatics parameters which basically influence the stability and other floating characteristics of ship at sea should be well analysed [1]. Ship hydrostatics parameters are properties of the immersed portion of the ship in water [2]. These parameters describe the characteristics of the underwater portion of the ship at a particular draught. If the ship is out of water, and draught becomes zero, then the parameters cease to exist [3].

Some of these parameters are mass displacement (MD), metacentric heights of vessels (MHV), longitudinal center of floatation (LCF), ship waterplane area (SWA), volume displacement (VD), centers of buoyancy (CB), moments of inertia of vessels (MIV), coefficients of form (CF), tons per centimeter immersion (TPCI), and wetted surface area
(WSA) [4-10]. All these parameters are important in ship stability. However, some parameters are more important than the other. Such parameters can be identified by developing and use of mathematical model under uncertainty. In view of this, a literature search is conducted on combination of fuzzy logic and analytical hierarchical process (AHP) in prioritization of importance of design/engineering parameters/criteria. The search revealed that there is a breakthrough in use of a fuzzy-analytical hierarchical process (Fuzzy-AHP) in solving similar problems as evidenced in the works of [11-19]. In view of the above cited references, the workability of the fuzzy-AHP method in prioritization exercise of engineering parameters under uncertainty is not in doubt. This research tends to close that gap of nonprioritization of the hydrostatic parameters in ship design and construction under uncertainty, so as to facilitate effective ship stability and optimal design process.

Therefore, the fuzzy-AHP method is adopted as a hybrid approach in investigation and selection of importance of ship hydrostatic parameters under 
uncertainty in this research. The structure of the paper is outlined as Section 2: Description of ship hydrostatic parameters; Section 3: Methodology; Section 4: Illustrative case study and Section 5: Conclusion.

\section{DESCRIPTION OF SHIP HYDROSTATIC PARAMETERS}

Ship hydrostatic parameters such as SWA, VD, MHV, MD, LCF, CB, TPCI, MIV, CF and WSA contribute in ship stability. They are important parameters and are described as follows:

\subsection{Ship Waterplane Area (SWA)}

The first ship hydrostatics parameter upon which others are derived or determined is the waterplane area of the ship $[3,7,10]$. It is the area of the plane surface of a vessel's hull at a particular waterline and it increases as the draught of the vessel increases [7]. Since ship hull is not a regular shape or body, mathematical models such as piecewise integration and simpson's rules are used to estimate the ship hull form.

\subsection{Volume Displacement (VD)}

The VD of a ship at any draught is the volume of water displaced as a ship moves in a particular density of water [9]. It indicates the hull type of the ship, whether the ship is a plaining hull, that is a type of ship hull where a small portion is submerged in water, or a displacement hull, which is a type of ship hull where a large portion of the hull is submerged in water [20]. This ship hydrostatic parameter enables the ship designer to properly match the ship to the particular capacity of propulsion system that will be required for optimal performance of the vessel [21].

\subsection{Mass Displacement (MD)}

When a ship floats, mass of water measured in tons is displaced. This mass of water that was displaced is called MD [3]. This ship hydrostatics parameter is dependent on volume displacement and the density of water the ship floats [7]. It is directly proportional to the volume displacement. MD as a hydrostatics parameter contributes in stabilization of the ship because it is equal to the weight of the ship in water [4].

\subsection{Metacentric Heights of Vessels (MHV)}

The metacentric height is another important ship hydrostatics parameters that influence the stability of a ship in water [3]. This parameter tells the distance between the point of the center of gravity of the ship (G) and the point of the metacenter (M), the metacenter of a ship is simply a point in the ship about which the ship oscillates when given an angular moment [22]. Metacentric heights can be transverse or longitudinal, their values can be positive, negative or neutral (zero). When the value is positive, it implies that the vessel is in stable equilibrium at the individual waterline but when the values become negative, it means that the vessel is in an unstable condition which may lead to capsize if the negativity increases to a certain critical value. Also when the GM value is zero, it implies that the vessel is in a neutral equilibrium that is the vessel will continue in the tilted or heeled condition until an external righting moment restores it to stable equilibrium [23].

\subsection{Longitudinal Center of Floatation (LCF)}

LCF is defined as a point in the waterplane area of a ship at which when load or weight is added on the ship, parallel sinkage is produced [4, 23]. This point normally lies along the longitudinal center line but not so for the transverse center line because it may drift a little forward or aft of amidship. Normally it may lie a distance of about three percent length forward and three percent length aft of amidships for oil tankers and containerships respectively. The Centre of floatation distance can be estimated with respect to the perpendiculars or the mid-ship [3, 4, 23].

\subsection{Centre of Buoyancy (CB)}

The centre of buoyancy is the geometrical center of the immersed portion of the ship body [8]. It can also be described as any point in the submerged area of the ship where the upthrust, upward or buoyant forces act to balance the vessel is called CB. The two types of centers of buoyancy are: vertical center of buoyancy $(\mathrm{KB})$ and longitudinal center of buoyancy (LCB). The CB is also the three-dimensional center of gravity of the underwater volume of the ship [24]. The vertical $\mathrm{CB}$ can be calculated using some methods such as "Vertical integration of waterplane method, approximate formula method and Integration of displacement curve method" [10].

\subsection{Tons Per Centimeter Immersion (TPCI)}

The TPCI is a hydrostatic parameter that is dependent on mass displacement and density of water the vessel is moving in [3]. It is very significant in ship stability because it tells how much or to what extent a ship can be submerged or sink under the addition of load and to what extent the ship is buoyed at the removal of load [8]. The TPCI of a ship floating in water of uniform density, depends solely on the area of waterplane [4]. This parameter enables Naval Architects to determine the stability of vessels as they add or remove weights or loads from vessels during ship design.

\subsection{The Moments of Inertia of Vessels (MIV)}

The MIV are hydrostatics parameters as evidenced in [3]. They are the measure of the ship's resistance to rotation or capsize [7, 23]. The three basic types of moments of inertia are moment of inertia about the ship's transverse section, moment of inertia about the longitudinal center of floatation, and moment of inertia about midship section. 


\subsection{Coefficients of Form (CF)}

In comparing ship's hull forms, displacements and dimensions, a number of coefficients are used in naval architecture [3, 7]. These coefficients are useful in power estimates and in expressing the fullness of a ship's overall form and those of the body plan sections and waterlines [25]. Also in ship design, it is often necessary to classify the hulls, so as to find the relationships between forms and their properties, especially the hydrodynamic properties. The CF is the most important means of achieving this.

\subsection{Wetted Surface Area (WSA)}

Wetted surface is defined as the total area of a vessel outside in contact with the surrounding water while afloat. The wetted surface may be used in estimating the amount of paint required to coat the vessel's bottom up to a given waterline. Also the wetted surface below the waterline may be added to area of the topsides above the waterline to obtain the total area of the shell plating $[7,26]$. Thus, the approximate weight of the shell may be estimated as well as the paint required for it. WSA is customarily calculated at various waterlines for a new ship and appears as one of the curves of form. In some cases, addition are made for appendages, such as stern, stern frame, rudder, propeller shaft bossing and bilge keels [27].

\section{METHODOLOGY}

The purpose of this research is to prioritize hydrostatic design parameters under uncertainty, so as to facilitate ship design process with sound engineering judgement. In view of the above, two techniques are used in this research as follows:

- Fuzzy logic: For addressing uncertainty due to ambiguity in pairwise comparison exercise,

- AHP: For prioritisation of the ship hydrostatic parameters in order of importance under uncertainty.

The fuzzy-AHP method is a useful tool in maritime and other industries. Karahalios et al. [15] used the fuzzy-AHP method to develop a System of Hierarchical Scorecards (SHS) that can assist regulators in evaluating any proposed and/or existing maritime regulations. [16] applied fuzzy-AHP method in analyzing the structure of the mooring system selection problem. In the works of [17], fuzzy-AHP method is applied to find the importance degree of each criterion as the measurable indices of regenerative technologies. In their study, eight kinds of regenerative technologies are assessed and ranked. Proper scale was identified as the most important criterion. The usefulness of fuzzy-AHP method has also been proved in the works of [18], which was employed in solving multi-criteria e-commerce problem. The fuzzy-AHP model is used in ranking e- commerce websites in e-alliance under uncertainty due to ambiguity. [19] demonstrated the effectiveness and feasibility of the proposed fuzzy-AHP model. The mechanism of fuzzy-AHP method is used in human error assessment and management in port operations in their work.

\subsection{AHP Technique}

The AHP method was developed by Saaty in 1977 to address multi-criteria decision making problems [28]. The usefulness of the technique has been evidenced in various studies $[15,16,29-39]$. The mechanism of the AHP technique can be used to facilitate ranking of parameters in decision making problems. The procedures of AHP technique can be outlined as follows:

- develop a hierarchical structure of the problem formulation, targeting/aiming decision making solution in the aforementioned problem,

- carry out pairwise comparison of criteria in the hierarchical structure of the revealed decision making problem using relevant formula,

- computation of weight of each criterion,

- rank the criterion in order of importance.

To achieve the procedures above, the following formulas below are employed [40]:

Average Numerical Value Rating $=\frac{\sum_{i=1}^{n} a_{i}}{n}$,

$$
\begin{aligned}
& T=\left[\begin{array}{cccc}
1 & a_{12} & \ldots & a_{1 L} \\
1 / a_{12} & 1 & \ldots & a_{2 L} \\
: & : & \ldots & : \\
: & : & & : \\
1 / a_{1 L} & 1 / a_{2 L} & \ldots & 1
\end{array}\right] \\
& w_{k}=\frac{1}{n} \sum_{j=1}^{n}\left(\frac{a_{k j}}{\sum_{i=1}^{n} a_{i j}}\right)(k=1,2,3 \ldots \ldots \ldots . . . n) \text {, } \\
& C R=\frac{C I}{R I}, \\
& C I=\frac{\lambda_{\max }-n}{n-1}, \\
& \lambda_{\max }=\frac{\sum_{j=1}^{n} \frac{\sum_{k=1}^{n} w_{k} a_{k j}}{w_{k}}}{n} .
\end{aligned}
$$

In Equation $1, n=$ the total number of designers involved in the pairwise comparison exercise of design criteria. $a_{i}=$ value estimated by designer $i$ for a criterion. Equation 1 is employed when experts involved in the pairwise comparison exercise are greater than one. 
In Equation 2, a pairwise comparison n-by-n matrix $\mathrm{T}$, is introduced to reveal the relative weights of the designed criteria. The pairwise comparison is facilitated using information provided in Table 1 . The matrix $\mathrm{T}$ stands for the quantified judgements on pairs of the design criteria and . Two entry rules are used to define the entries in Equation 2. The rules are [40]:

Rule 1. If $a_{i j}=\alpha$, then $a_{j i}=1 / \alpha, \alpha \neq 0$.

Rule 2. If $A_{i}$ is judged to be of equal relative importance as $A_{j}$, then $a_{i j}=a_{j i}=1$.

Equation 3 is used to estimate the relative weights of the criteria, $\boldsymbol{A}_{i}$ and $\boldsymbol{A}_{j}, \quad$ and $i, j=1,2,3 \ldots \ldots$, . Where $\mathrm{w}_{\mathrm{k}}=$ relative weight $(k=1,2,3 \ldots \ldots \ldots . n) . a_{i j}(i, j=1,2 \ldots . . L)=$ the entry of row $i$ and column $j$ in a comparison matrix of order $n$.

Equation 4 is used to check if $w_{k}$ values associated with the criteria $A_{i}$ and $A_{j}$ are reasonable. CR stands for consistency ratio. CI stands for consistency index value. RI stands for random index value. $w_{k}$ values established are reasonable and acceptable if the Consistency Ratio (CR) is less than or equal to 0.10 [33]. Though this value has not been proved mathematically [15]. In view of this, Saaty suggested that $C R$ value could be near 0.2 to accommodate justifiable judgement of the experts [41, 42]. Furthermore, in real world it is not easy to achieve this value due to various experts experiences [15]. Table 2 is used to indicate the values of RI.

Equation 5 is used to show the relationship of CI, $\lambda_{\max }$, and $\mathrm{n}$ values. $\mathrm{n}$ stands for the matrix order. $\lambda_{\max }$ stands for the maximum weight value of the $n-b y-n$ comparison matrix T. Equation 6 is used to estimate $\lambda_{\max }$

\subsection{Fuzzy Set Theory}

Zadeh introduces fuzzy set theory in 1965 [43]. It is one of the powerful artificial intelligence technique that can be used to solve engineering problems in realm of uncertainty. It uses the concept of linguistic variables $[19,44,45]$. The relevance of the technique and its mechanism has been demonstrated in various publications [19, 44-52]. A triangular fuzzy number $\widetilde{A}=\left(a_{1}, a_{2}, a_{3}\right)$ membership function illustrated in Figure 1 is defined as follows:

$$
\mu(x)=\left\{\begin{array}{ll}
0 & x \leq a \\
\left(x-a_{1}\right) /\left(a_{2}-a_{1}\right) & a_{1} \leq x \leq a_{2} \\
\left(a_{3}-x\right) /\left(a_{3}-a_{2}\right) & a_{2} \leq x \leq a_{3} \\
0 & x \geq a_{3}
\end{array} .\right.
$$

Fuzzy number addition and reciprocal are expressed in Equations 8 and 9.

$$
\begin{gathered}
\left(a_{11}, a_{12}, a_{13}\right) \oplus\left(a_{21}, a_{22}, a_{23}\right)=\left(a_{11}+a_{21}, a_{12}+a_{22}, a_{13}+a_{23}\right),(8) \\
\left(a_{1}, a_{2}, a_{3}\right)^{-1}=\left(1 / a_{1}, 1 / a_{2}, 1 / a_{3}\right) .
\end{gathered}
$$

The fuzzy numbers can be converted to crisp values using centre of area (CoA) defuzzification method. The CoA defuzzification method was developed by Sugeno in 1985 [53]. The method is described as follows:

$$
X^{*}=\frac{\int \mu_{i}(x) x d x}{\int \mu_{i}(x) d x},
$$

where $X^{*}=$ Defuzzified output.

$\mu_{i}(x)=$ Aggregated membership function

$x=$ Output variable

In view of the above, a triangular fuzzy number $\widetilde{A}=\left(a_{1}, a_{2}, a_{3}\right)$ shown in Figure 1, can be defuzzified as follows:

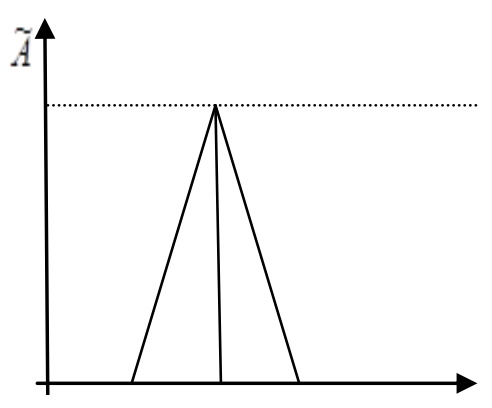

Fig. 1. A Triangular Fuzzy Number $\tilde{A}$

$$
\begin{gathered}
X^{*}=\frac{\int_{a_{1}}^{a_{2}} \frac{x-a_{1}}{a_{2}-a_{1}} x d x+\int_{a_{3}}^{a_{2}} x d x+\int_{a_{4}}^{a_{3}} \frac{a_{4}-x}{a_{4}-a_{3}} x d x}{\int_{a_{1}}^{a_{2}} \frac{x-a_{1}}{a_{2}-a_{1}} d x+\int_{a_{2}}^{a_{3}} d x+\int_{a_{3}}^{a_{4}} \frac{a_{4}-x}{a_{4}-a_{3}} d x}, \\
=\frac{1}{3}\left(a_{1}+a_{2}+a_{3}\right) .
\end{gathered}
$$


Tab. 1. Comparison Scale for Assessment Grades of the Criteria

\begin{tabular}{|c|c|c|}
\hline $\begin{array}{l}\text { Intensity of } \\
\text { Importance }\end{array}$ & Definition & Description \\
\hline 1 & $\begin{array}{l}\text { Equal } \\
\text { importance } \\
\text { (EI) }\end{array}$ & $\begin{array}{l}\text { Indicates that the levels of importance of two hydrostatic } \\
\text { parameters/criteria are equal in facilitation of ship design process. }\end{array}$ \\
\hline 2 & Weak (W) & $\begin{array}{l}\text { Indicates that the levels of importance of two hydrostatic } \\
\text { parameters/criteria are between equal importance and moderate } \\
\text { importance in facilitation of ship design process. }\end{array}$ \\
\hline 3 & $\begin{array}{l}\text { Moderate } \\
\text { importance } \\
\text { (MI) }\end{array}$ & $\begin{array}{l}\text { Indicates that a hydrostatic parameter/criterion is slightly important } \\
\text { over another hydrostatic design parameter/criterion in facilitation of } \\
\text { ship design process. }\end{array}$ \\
\hline 4 & $\begin{array}{l}\text { Moderate plus } \\
\text { (MP) }\end{array}$ & $\begin{array}{l}\text { Indicates that a hydrostatic parameter/criterion is between moderate } \\
\text { importance and strong importance over another hydrostatic } \\
\text { parameter/criterion in facilitation of ship design process. }\end{array}$ \\
\hline 5 & $\begin{array}{l}\text { Strong } \\
\text { importance } \\
(\mathrm{SI})\end{array}$ & $\begin{array}{l}\text { Indicates that a hydrostatic parameter/criterion is strongly } \\
\text { favour/importance over another hydrostatic parameter/criterion in } \\
\text { facilitation of ship design process. }\end{array}$ \\
\hline 6 & $\begin{array}{l}\text { Strong plus } \\
(\mathrm{SP})\end{array}$ & $\begin{array}{l}\text { Indicates that a hydrostatic parameter/criterion is between strong } \\
\text { importance and very strong importance over another hydrostatic } \\
\text { parameter/criterion in facilitation of ship design process. }\end{array}$ \\
\hline 7 & $\begin{array}{l}\text { Very strong } \\
\text { importance } \\
\text { (VSI) }\end{array}$ & $\begin{array}{l}\text { Indicates that a hydrostatic parameter/criterion is very strongly } \\
\text { importance over another hydrostatic design parameter/criterion in } \\
\text { facilitation of ship design process. }\end{array}$ \\
\hline 8 & $\begin{array}{l}\text { Very highly } \\
\text { strong (VHS) }\end{array}$ & $\begin{array}{l}\text { Indicates that a hydrostatic parameter/criterion is between strong } \\
\text { importance and very strong importance over another hydrostatic } \\
\text { design parameter/criterion in facilitation of ship design process. }\end{array}$ \\
\hline 9 & $\begin{array}{l}\text { Extreme } \\
\text { importance } \\
\text { (EI) }\end{array}$ & $\begin{array}{l}\text { Indicates that a hydrostatic parameter/criterion is extreme } \\
\text { importance over another hydrostatic design parameter/criterion in } \\
\text { facilitation of ship design process. }\end{array}$ \\
\hline
\end{tabular}

Tab. 2. Value of Average Random Index (RI) versus Matrix Order [33]

\begin{tabular}{|c|c|c|c|c|c|c|c|c|c|c|}
\hline $\mathrm{n}$ & 1 & 2 & 3 & 4 & 5 & 6 & 7 & 8 & 9 & 10 \\
\hline RI & 0 & 0 & 0.58 & 0.90 & 1.12 & 1.24 & 1.32 & 1.41 & 1.45 & 1.49 \\
\hline
\end{tabular}

\subsubsection{Development of Comparison Scale for Assessment Grades of the Criteria in Fuzzy Environment}

The relationship of the fuzzy logic and AHP technique is facilitated using information provided in Table 1 and Figure 2 to develop Table 3. Table 3 will provide a platform for application/ implementation of pairwise comparison of ship hydrostatic parameters exercise in combination with relevant formulas in Section 4. Table 3 is important due to existence of uncertainty in judgement of the pairwise comparison exercise by designers. This subdue the challenges associated with application of an AHP technique as a stand-alone, thus giving rise to combination of the AHP technique with fuzzy logic. The hybrid approach is the most effective method that can address the fuzziness of the data associated with parameters in pairwise comparison exercise by various designers. 


\section{ILLUSTRATIVE CASE STUDY}

In this research, a combination of AHP and fuzzy logic as hybrid approach is applied in investigation of importance of ship hydrostatic parameters over another. Ship hydrostatic parameters have been described in Section 2. The ship hydrostatic parameters under investigation are identified and outlined as MD, MHV, LCF, SWA, VD, CB, MIV, CF, TPCI and WSA.

EI W MI MP SI SP VSI VHS EIM

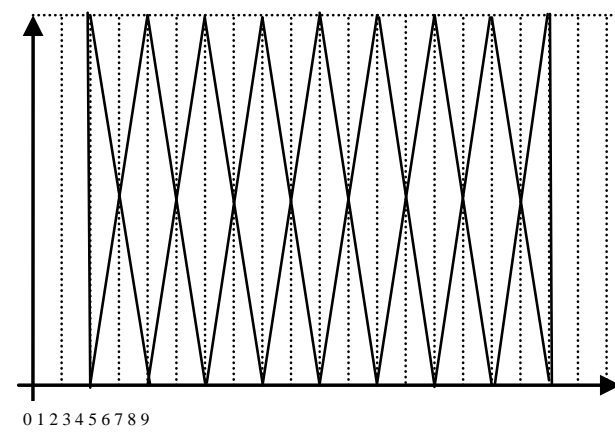

Fig. 2. A Representation of Linguistic Terms in Triangular Fuzzy Membership Function Form

\subsection{Development of a Hierarchical Structure of the Problem Formulation}

The problem formulation is prioritization of ship hydrostatic parameters under uncertainty using fuzzy-AHP approach. To address this engineering challenge, a hierarchical structure is developed in Figure 3. The Figure 3 reveals the purpose of the study, which is ranking of the hydrostatic design parameters and the parameters involved.

\subsection{Pairwise Comparison of Hydrostatic Design Criteria/Parameters in Fuzzy Environment}

Pairwise comparison of hydrostatic parameters/criteria is conducted to facilitate estimation of their individual weights in fuzzy environment. Fuzzy logic address uncertainty associated with estimation of designers' opinion. In this study, service of three designers is employed in the pairwise comparison exercise. The designers have equal experience in the subject under investigation, thus Equation 1 will be employed in aggregation of their experiences.

In the pairwise comparison exercise under uncertainty, the serial nos. 1-45 have corresponding aggregated fuzzy estimates of $(14,17,20),(22,25$, $27),(7,10,13),(5,8,11),(4,7,10),(16,19,22)$, $(19,22,25),(23,26,27),(10,13,16),(5,8,11)$, $(14,17,20),(19,22,25),(5,8,11),(4,7,10),(20$, $23,26),(23,26,27),(4,7,10),(11,14,17),(6,9$, 12), (10, 13, 16), (21, 24, 27), (7, 10, 13), (14, 17, $20),(19,22,25),(7,10,13),(4,7,10),(16,19,22)$, $(23,26,27),(22,25,27),(7,10,13),(8,11,14),(16$, 20, 23), (22, 25, 27), (7, 10, 13), (8, 11, 14), (19, 22, $25),(11,14,17),(20,23,26),(22,25,27),(5,8,11)$, $(11,14,17),(13,16,19),(8,11,14),(17,20,23)$ and $(16,19,22)$ respectively (See Table A1 in Appendix for details). The fuzzy estimates are obtained using Equation 8. These values are produced/calculated using Equation 1. These fuzzy estimates/values are defuzzified using Equation 12. Their corresponding crisp values are 5.67, 8.22, $3.32,2.65,2.32,6.33,7.33,8.45,4.33,2.67,5.67$, $7.33,2.67,2.33,7.67,8.45,2.32,4.67,3,4.33,8$, $3.33,5.67,7.33,3.33,2.33,6.33,8.45,8.22,3.33$, $3.67,6.33,8.22,3.33,3.67,7.33,4.67,7.67,8.22$, $2.67,4.67,5.33,3.67,6.67$ and 6.33 respectively as evidenced in Table A1 of Appendix.

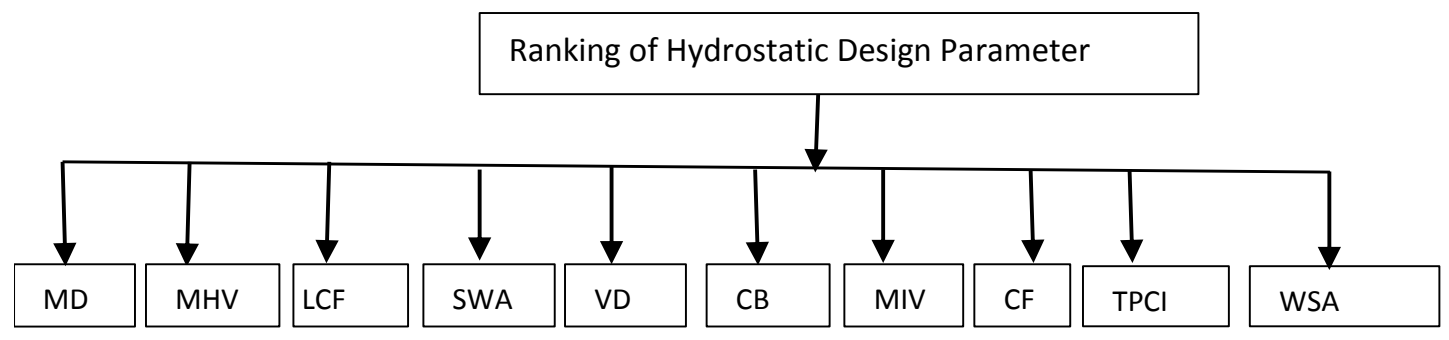

Fig. 3. A Hierarchical Structure for Ship Hydrostatic Parameters/Criteria 
Tab. 3. Comparison Scale for Assessment Grades of the Criteria in Fuzzy Environment

\begin{tabular}{|c|c|c|c|}
\hline $\begin{array}{l}\text { Intensity of } \\
\text { importance }\end{array}$ & Fuzzy Number & Definition & Description \\
\hline 1 & $(1,1,2)$ & Equal importance (EI) & $\begin{array}{l}\text { Indicates that the levels of importance of two } \\
\text { hydrostatic parameters/criteria are equal in } \\
\text { facilitation of ship design process. }\end{array}$ \\
\hline 2 & $(1,2,3)$ & Weak (W) & $\begin{array}{l}\text { Indicates that the levels of importance of two } \\
\text { hydrostatic parameters/criteria are between equal } \\
\text { importance and moderate importance in facilitation } \\
\text { of ship design process. }\end{array}$ \\
\hline 3 & $(2,3,4)$ & $\begin{array}{l}\text { Moderate importance } \\
\text { (MI) }\end{array}$ & $\begin{array}{l}\text { Indicates that a hydrostatic parameter/criterion is } \\
\text { slightly important over another hydrostatic } \\
\text { parameter/criterion in facilitation of ship design } \\
\text { process. }\end{array}$ \\
\hline 4 & $(3,4,5)$ & Moderate plus (MP) & $\begin{array}{l}\text { Indicates that a hydrostatic parameter/criterion is } \\
\text { between moderate importance and strong } \\
\text { importance over another hydrostatic } \\
\text { parameter/criterion in facilitation of ship design } \\
\text { process. }\end{array}$ \\
\hline 5 & $(4,5,6)$ & Strong importance (SI) & $\begin{array}{l}\text { Indicates that a hydrostatic parameter/criterion is } \\
\text { strongly favour/importance over another hydrostatic } \\
\text { parameter/criterion in facilitation of ship design } \\
\text { process. }\end{array}$ \\
\hline 6 & $(5,6,7)$ & Strong plus (SP) & $\begin{array}{l}\text { Indicates that a hydrostatic parameter/criterion is } \\
\text { between strong importance and very strong } \\
\text { importance over another hydrostatic } \\
\text { parameter/criterion in facilitation of ship design } \\
\text { process. }\end{array}$ \\
\hline 7 & $(6,7,8)$ & $\begin{array}{l}\text { Very strong importance } \\
\text { (VSI) }\end{array}$ & $\begin{array}{l}\text { Indicates that a hydrostatic parameter/criterion is } \\
\text { very strongly importance over another hydrostatic } \\
\text { parameter/criterion in facilitation of ship design } \\
\text { process. }\end{array}$ \\
\hline 8 & $(7,8,9)$ & $\begin{array}{l}\text { Very highly strong } \\
\text { (VHS) }\end{array}$ & $\begin{array}{l}\text { Indicates that a hydrostatic parameter/criterion is } \\
\text { between strong importance and very strong } \\
\text { importance over another hydrostatic } \\
\text { parameter/criterion in facilitation of ship design } \\
\text { process. }\end{array}$ \\
\hline 9 & $(8,9,9)$ & $\begin{array}{l}\text { Extreme importance } \\
\text { (EI) }\end{array}$ & $\begin{array}{l}\text { Indicates that a hydrostatic design } \\
\text { parameter/criterion is extreme importance over } \\
\text { another hydrostatic parameter/criterion in } \\
\text { facilitation of ship design process. }\end{array}$ \\
\hline
\end{tabular}

\section{CONCLUSIONS}

A fuzzy-AHP method has been utilised in analysis and calculation of importance of hydrostatic parameters in realm of uncertainty, so as to facilitate ship design process. Importance of ship hydrostatic parameters over another has been revealed using the fuzzy-AHP model. The numerical illustration in Section 4 exposed that MIV is more important than other parameters because is associated with weight value of 0.46 , thus ranked as 1 . Furthermore, WSA is ranked as 10 because of its weight value of 0.028 , which is an indication is the least importance parameter. Other parameters such as MD, MH, LCF, SWA, VD, CB, CF and TPCI are associated with weights of $0.218,0.095,0.078,0.083,0.074,0.1$, 0.108 , and 0.209 respectively. Their respective corresponding ranks are 2, 6, 8, 7, 9, 5, 4 and 3. Ship construction companies can adopt this model in their decision making process during the design of a ship. 


\section{Nomenclature}

Symbols

$$
\begin{aligned}
& a_{i} \quad \text { - Value estimated for designer i for a criterion } \\
& n \quad-\text { Total number of designers involved in the pairwise }
\end{aligned}
$$

$a_{k j}$

- Summed estimated value on column j in comparison matrix $T$

CR - Consistency ratio

CI - Consistency index value

RI - Random index value

$\lambda_{\max } \quad$ - Maximum weight value of the $n$-by-n comparison matrix $T$

$\widetilde{A}$

- Triangular fuzzy number with membership function $\left(a_{1}, a_{2}, a_{3}\right)$

$X^{*} \quad-$ Defuzzified output

$\mu_{i}(x)$

- Aggregated membership function

$x \quad$ - Output variable

\section{Acronyms}

$\begin{array}{ll}\text { AHP } & - \text { Analytical Hierarchical Process } \\ \text { MIV } & - \text { Moments of Inertia of Vessels } \\ \text { MD } & \text { - Mass Displacement } \\ \text { TPCI } & - \text { Tons Per Centimeter Immersion } \\ \text { CF } & - \text { Coefficients of Form } \\ \text { CB } & - \text { Centers of Buoyancy } \\ \text { MHV } & - \text { Metacentric Heights of Vessels } \\ \text { SWA } & - \text { Ship Waterplane Area } \\ \text { LCF } & - \text { Longitudinal Center of Floatation } \\ \text { VD } & - \text { Volume Displacement } \\ \text { WSA } & - \text { Wetted Surface Area }\end{array}$

\section{References}

1. Aryanpour, M., Gorashi, M. (2011). Heave and pitch motions of a ship due to moving mass and forces. Journal of Sound and Vibration, Vol. 241, No. 2, pp. 183-195.

2. Bagahari, Hassan, G. (2014). Optimization of wigley hull form in order to ensure the objective function of the seakeeping performance. Journal of Marine Science and Application, Vol. 3, No. 7, pp. 55-71.

3. Biran, A., Pulido, R. L. (2013). Ship hydrostatics and stability. 2th Edition, Butterworth-Heinmann, London, United Kingdom.

4. Chakraborty, S. (2019). Ship Stability - Introduction to hydrostatics and stability of surface ships. https://www.marineinsight.com/naval-architecture/shipstability-introduction-hydrostatics-stability-surfaceships/ Accessed On 01/01/2019.
5. Miller, A. W., Davidson, I. C., Minton, M. S., Steves, B., Moser, C. S., Drake, L.A., Ruiz, G.M. (2018). Evaluation of wetted surface area of commercial ships as biofouling habitat flux to the united states. Biological Invasions, Vol. 20, Issue 8, pp. 1977-1990.

6. Moser, C. S., Wier, T. P., Grant, J. F., First, M. R., Tamburri, M. N., Ruiz, G. M. (2016). Quantifying the total wetted surface area of the world fleet: a first step in determining the potential extent of ships' biofouling. Biological Invasions, Vol. 18, Issue 1, pp. 265-277.

7. Tupper, E. C. (2013). Introduction to naval architecture. 5th Edition, Butterworth- Heinmann, London, United Kingdom.

8. Ueng, S. K. (2013). Physical models for simulating ship stability and hydrostatic motions. Journal of Marine Science and Technology, Vol. 21, No. 6, pp. 674-685.

9. Liu, L., Yougang, T. (2007). Stability of ship with water on deck at random beam waves. Journal of Vibration and Control, Vol. 13, No. 3, pp. 269-270.

10. Lewis, E. V. (1988). Principles of naval architecture. volume 1, stability and strength. 2nd Edition, The Society of Naval Architecture and Marine Engineers, New Jersey, USA.

11. Wang, Y., Jung, K. A., Yeo, G.T. Chou, C. C. (2014). Selecting a cruise port of call location using the fuzzyAHP method: a case study in East Asia. Tourism Management, Vol. 42, pp. 262-270.

12. Ying, X., Zeng, G.M., Chen, G.Q., Tang, L., Wang, K.L., Huang, D.Y. (2007). Combining AHP with GIS in synthetic evaluation of eco-environment quality - a case study of Hunan Province, China. Ecological Modelling, 209, No. 2, pp. pp.97-109.

13. Sahin, B., Yip, T. L. (2017). Shipping technology selection for dynamic capability based on improved Gaussian fuzzy AHP model. Ocean Engineering, Vol. 136, pp, 233-242.

14. Beşikçi, E. B., Kececi, T., Arslan, O., Turan, O. (2016). An application of fuzzy-AHP to ship operational energy efficiency measures. Ocean Engineering, Vol. 121, pp. 392-402.

15. Karahalios, H., Yang, Z. L., Williams, V. Wang, J. (2011). A proposed system of hierarchical scorecards to assess the implementation of maritime regulations. Safety Science, Vol. 49, pp. 450-462.

16. Mentes, A., Helvacioglu, I. H. (2012). Fuzzy decision support system for spread mooring system selection. Expert Systems with Applications, Vol. 39, pp. 32833297.

17. Hsu, Y. L., Lee, C. H., Kreng, V. B. (2010). The application of fuzzy delphi method and fuzzy AHP in lubricant regenerative technology selection. Expert Systems with Applications, Vol. 37, pp. 419-425.

18. Yu, X., Guo, S., Guo, J., Huang, X. (2011). Rank B2C ecommerce websites in e-alliance based on ahp and fuzzy topsis. Expert Systems with Applications, Vol. 38, pp. 3550-3557.

19. Ung, S. T., Williams, V., Chen, H. S., Bonsall, S., Wang, J. (2006). Human error assessment and management in port operations using fuzzy AHP. Marine Technology Society Journal, Vol. 40, No. 1, pp. 73-86.

20. Kato, H. (2005). Effect of bilge keel on the rolling of ship. Journal of Society of Naval Architects, Vol. 117, No. 3, pp. 93-114.

21. Gu, J. Y. (2006). Calculation of ship rolling probability using a new path integration method. Journal of Ship Mechanics, Vol. 10, No. 6, pp. 43-52.

22. Malenica, B., Molin, S. (2009). Hydrostatic response of a barge to impulsive and nonimpulsive wave loads. Journal of Marine Science and Technology, Vol. 5, No. 3, pp. 11-23. 
23. Stokoe, E. A. (2002). Reed's naval architecture for marine engineers. 2nd Edition, Thomas Reed, London.

24. Molenica, S., Senjanovic, I. (2007). Some aspects of hydrostatic issues in the design of ultra large container ship. Journal of Marine Science and Technology, Vol. 9, No. 5, pp. 211-230.

25. Kuiper, G. (1990). Preliminary design of ship lines by mathematical methods. Journal of Ship Research, Vol. 1, No. 2, pp. 30-45.

26. Derrett, D. R., Barrass, C. B. (2001). Ship stability for masters and mates. 5th Edition, Elsevier, Johannesburg, South Africa.

27. Rawson, J., Tupper, E. C. (2001). Basic ship theory, hydrostatics and strength. Butterworth-Heinemann,5th Edition, Oxford, London, United Kingdom.

28. Saaty, T. L. (1977). Scaling method for priorities in hierarchical structures. Journal of Mathematical Psychology, Vol. 15, No 3, pp. 234-281.

29. Nwaoha, T. C., Ashiedu, F. I. (2015). Engineering judgment in wheelchair design criteria: an analytical hierarchy process (AHP) approach. Journal of Sustainable Technology, Vol. 6, No. 2, pp. 32-42.

30. Hambali, A., Sapuan, S. M., Ismail, N., Nukman, Y. (2009). Application of analytical hierarchy process in the design concept selection of automotive composite bumper beam during the conceptual design stage. Scientific Research and Essay, Vol. 4, No. 4, pp. 198211

31. Guy, E. and Urli, B. (2006), "Port selection and multicriteria analysis: an application to the Montrealnewyork alternative. Maritime Economics and Logistics, Vol. 8, pp. 169-186.

32. Chang, Y. T., Lee, S. Y., Tongzon, J. L. (2008). Port selection factors by shipping lines: different perspectives between trunk liners and feeder service providers. Marine Policy, Vol. 32, No. 6, pp. 877-885.

33. Saaty, T. L. (1980), "The analytic hierarchy process. McGraw-Hill, New York, pp. 1-287.

34. Chan, F., Kumar, N. (2007). Global supplier development considering risk factors using fuzzy extended ahp-based approach. Omega, Vol. 35, pp. 417431

35. Arslan, O. (2009). Quantitative evaluation of precautions on chemical tanker operations. Process Safety and Environmental Protection, Vol. 87, pp. 113-120.

36. Lavasani, S. M. M., Yang, Z., Finlay, J., Wang, J (2011). Fuzzy risk assessment of oil and gas offshore wells. Process Safety and Environmental Protection, Vol. 89, pp. 277-294.

37. Song, D. W., Yeo, K. T. (2004). A competitive analysis of chinese container port using the analytic hierarchy process. Maritime Economics and Logistics, Vol. 6, 3452.

38. Lirn, T. C., Thanopoulou, H. A., Beresford, A. K. C. (2003). Transhipment port selection and decision-making behaviour: analysing the taiwanese case. International Journal of Logistics-Research and Applications, Vol. 6, pp. 229-244.

39. Lirn, T. C., Thanopoulou, H. A., Beresford, A. K. C. (2004). An application of ahp on transshipment port selection: a global perspective. Maritime Economics and Logistics, Vol. 6, pp. 70-91.

40. Riahi, R., Bonsall, S., Jenkinson, I.,Wang, J. (2012). A Seafarer's Reliability Assessment Incorporating Subjective Judgements. Journal of Engineering for Maritime Environment, Vol. 226, No. 4, pp. 313-334.

41. Dadkhah, K. M., Zahedi, F. (1993). A mathematical treatment of inconsistency in the analytic hierarchy process. Mathematical Computing Modeling, Vol. 17, No. 415, pp. 111-122.
42. Wedley, W.C. (1993). Consistency prediction for incomplete ahp matrices. Mathematical Computing Modeling, Vol. 17, No. 415, pp. 151-161.

43. Zadeh, L. A. (1965). Fuzzy Set. Information and Control, Vol. 8. pp. 338-353.

44. Sii, H. S., Ruxton, T., Wang, J. (2001). A fuzzy-logicbased approach to qualitative safety modelling for marine systems. Reliability Engineering and System Safety, Vol. 73, pp.19-34.

45. Nwaoha, T. C., John, A., Adumene, S. (2017a). Incorporation of novel model in failure analysis of propeller operations of sea going vessels. Ships and Offshore Structures, Vol. 12, Issue 1, pp. 9-18.

46. Kanagaraj, N., Sivashanmugam, P. Paramasivam, S., (2009). A Fuzzy logic based supervisory hierarchical control scheme for real time pressure control. International Journal of Automation and Computing, Vol. 6, Issue 1, pp. 88-96.

47. John, A., Nwaoha, T. C., Kpangbala, T. M. (2017). A collaborative modelling of ship and port operations interface under uncertainty. Journal of Engineering for Maritime Environment, Vol. 231, Issue 1, pp. 165-176.

48. Nwaoha, T.C (2014). Inclusion of hybrid algorithm in optimal operations of LNG transfer arm under uncertainty. Ships and Offshore Structures, Vol. 9, Issue 5, pp. 514-524.

49. Nwaoha, T. C., Adumene, S., Thankgod, B. E. (2017b). Modelling prevention and reduction methods of ship propeller cavitation under uncertainty. Ships and Offshore Structures, Vol. 12, Issue 4, pp. 452-460.

50. Nwaoha, T.C., Ombor, G., Okwu, M. O. (2017c). A combined algorithm approach to fuel consumption rate analysis and prediction of sea-worthy diesel engine powered marine vessels. Journal of Engineering for Maritime Environment, Vol. 231, Issue 2, pp. 542-554.

51. Kwong, K.C., Bai, H., (2003). Determining the importance weights for the customer requirements in QFD using a fuzzy AHP with an extent analysis approach. IIE Transactions, Vol. 35, pp. 619-626.

52. Chen, S. J., Chen, S.M., (2005). Aggregating Fuzzy Opinions in the Heterogeneous Group Decision-making Environment. Cybernetics and Systems: An International Journal, Vol. 36, pp. 309-338.

53. Sugeno, M. (1999), "Fuzzy Modelling and Control", 1st. Edition, CRC Press, Florida, USA.

\section{Biographical notes}

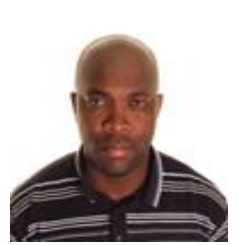

Thaddeus Chidiebere Nwaoha obtained his $\mathrm{PhD}$ in Marine and Offshore Engineering and MSc in Marine and Offshore Engineering from Liverpool John Moores University, UK in 2011 and 2006 respectively. His professional experiences comprise of academic and industrial experiences in LNG carrier system maintenance and risk modeling, inspection of topside and subsea equipment, quality assurance, safety, risk and reliability analysis of marine and offshore systems. He has served as an inspection, quality assurance, safety and reliability engineer in marine and offshore companies and a member of professional bodies such as IMarEST, NSE and COREN. Since 2010, he has authored and co-authored more than 35 journal papers in world leading journals and one of his papers was nomination for SAGE 2011 best paper award in Journal of Engineering for Maritime Environment. His research interests are marine and offshore system failure analysis, design for safety of marine and offshore systems, optimization, maintenance modeling and risk/reliability 
analysis. Currently, he serves as a Senior Lecturer in Marine Engineering Department, Federal University of Petroleum Resources, Nigeria.

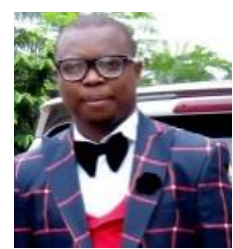

Idubor Fabian Ifeanyi is a Lecturer in the Department of Marine Engineering, College of Technology, Federal University of Petroleum Resources Effurun Delta State, Nigeria. He holds a BEng in Marine Engineering and a MSc in Naval Architecture and Ship Building, both from Rivers State University, Portharcourt, Nigeria. He also hold an Ordinary National Diploma in Electrical / Electronic Engineering Department from Federal Polytechnic Oko, Anambra State. His area of specialization are Ship Power Plant, Naval Architecture, Ship Structural and Stability Analyses.

\section{Appendix}

Weights Estimation of Hydrostatic Parameters/Criteria in Fuzzy Environment

Weight of $\mathrm{MD}=\frac{1}{10}\left[\frac{1}{3.05}+\frac{5.67}{24.712}+\frac{8.22}{25.67}+\frac{3.32}{26.116}+\right.$ $\left.\frac{2.65}{26.892}+\frac{2.32}{18.461}+\frac{6.33}{43.569}+\frac{7.33}{28.124}+\frac{8.45}{18.794}+\frac{4.33}{43.308}\right]=$ 0.218

Weight of $\mathrm{MH}=\frac{1}{10}\left[\frac{0.176}{3.05}+\frac{1}{24.712}+\frac{2.67}{25.67}+\frac{5.67}{26.116}+\right.$ $\left.\frac{7.33}{26.892}+\frac{2.67}{18.461}+\frac{2.33}{43.569}+\frac{0.13}{28.124}+\frac{0.118}{18.794}+\frac{2.32}{43.308}\right]=$ 0.095

Weight of $\mathrm{LCF}=\frac{1}{10}\left[\frac{0.122}{3.05}+\frac{0.375}{24.712}+\frac{1}{25.67}+\frac{4.67}{26.116}+\right.$ $\left.\frac{0.33}{26.892}+\frac{0.231}{18.461}+\frac{8}{43.569}+\frac{3.33}{28.124}+\frac{0.176}{18.794}+\frac{7.33}{43.308}\right]=$ 0.078

Weight of SWA $=\frac{1}{10}\left[\frac{0.301}{3.05}+\frac{0.176}{24.712}+\frac{0.214}{25.67}+\frac{1}{26.116}+\right.$ $\left.\frac{3.33}{26.892}+\frac{0.429}{18.461}+\frac{6.33}{43.569}+\frac{8.45}{28.124}+\frac{0.122}{18.794}+\frac{3.33}{43.308}\right]=$ 0.083

Weight of VD $=\frac{1}{10}\left[\frac{0.377}{3.05}+\frac{0.136}{24.712}+\frac{3}{25.67}+\frac{0.3}{26.116}+\right.$ $\left.\frac{1}{26.892}+\frac{3.67}{18.461}+\frac{6.33}{43.569}+\frac{0.122}{28.124}+\frac{0.3}{18.794}+\frac{3.67}{43.308}\right]=$ 0.074

Weight of $\mathrm{CB}=\frac{1}{10}\left[\frac{0.431}{3.05}+\frac{0.375}{24.712}+\frac{4.33}{25.67}+\frac{2.33}{26.116}+\right.$ $\left.\frac{0.272}{26.892}+\frac{1}{18.461}+\frac{7.33}{43.569}+\frac{4.67}{28.124}+\frac{0.13}{18.794}+\frac{8.22}{43.308}\right]=$ 0.1

Weight of $\mathrm{MIV}=\frac{1}{10}\left[\frac{0.158}{3.05}+\frac{0.429}{24.712}+\frac{0.125}{25.67}+\right.$ $\frac{0.158}{26.116}+\frac{0.158}{26.892}+\frac{0.136}{18.461}+\frac{1}{43.569}+\frac{2.67}{28.124}+\frac{4.67}{18.794}+$ $\left.\frac{0.188}{43.308}\right]=0.046$
Weight of $\mathrm{CF}=\frac{1}{10}\left[\frac{0.136}{3.05}+\frac{7.67}{24.712}+\frac{0.3}{25.67}+\frac{0.118}{26.116}+\right.$ $\left.\frac{8.22}{26.892}+\frac{0.214}{18.461}+\frac{0.375}{43.569}+\frac{1}{28.124}+\frac{3.67}{18.794}+\frac{6.67}{43.308}\right]=$ 0.108

Weight of $\mathrm{TPCI}=\frac{1}{10}\left[\frac{0.118}{3.05}+\frac{8.45}{24.712}+\frac{5.67}{25.67}+\right.$ $\frac{8.22}{26.116}+\frac{3.33}{26.892}+\frac{7.67}{18.461}+\frac{0.214}{43.569}+\frac{0.272}{28.124}+\frac{1}{18.794}+$ $\left.\frac{6.33}{43.308}\right]=0.209$

Weight of WSA $=\frac{1}{10}\left[\frac{0.231}{3.05}+\frac{0.431}{24.712}+\frac{0.136}{25.67}+\frac{0.3}{26.116}+\right.$ $\left.\frac{0.272}{26.892}+\frac{0.122}{18.461}+\frac{5.33}{43.569}+\frac{0.15}{28.124}+\frac{0.158}{18.794}+\frac{1}{43.308}\right]=$ 0.028

\section{Estimation of CR value under Uncertainty}
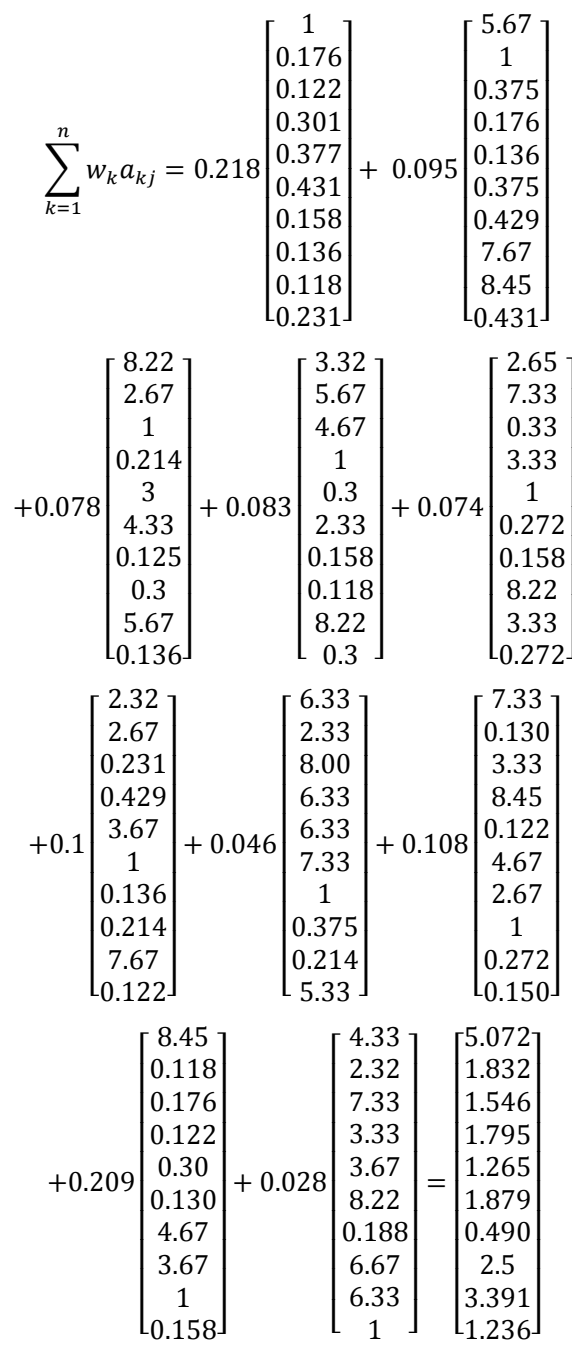


$$
\begin{array}{ll}
\lambda_{\max }=\frac{\sum_{j=1}^{n} \frac{\sum_{k=1}^{n} w_{k} a_{k j}}{w_{k}}}{n} & =21.40 \\
\frac{5.072}{0.218}+\frac{1.832}{0.095}+\frac{1.546}{0.078}+\frac{1.795}{0.083}+\frac{1.265}{0.074}+\frac{1.879}{0.1}+\frac{0.49}{0.046}+ & C R=\frac{C 1}{R 1}=\frac{C 1}{1.49} \\
=\frac{\frac{2.5}{0.108}+\frac{3.391}{0.209}+\frac{1.236}{0.028}}{10} & C 1=\frac{\lambda_{\max }-n}{n-1}=\frac{21.40-10}{10-1}=\frac{11.40}{9}=1.267 \\
\frac{23.27+19.28+19.82+21.63+17.09+18.79}{+10.65+23.15+16.22+44.14} & C R=\frac{1.267}{1.49}=0.85 \\
\hline &
\end{array}
$$

\begin{tabular}{|c|c|c|c|c|c|c|c|c|c|}
\hline $\mathrm{S} / \mathrm{N}$ & $\begin{array}{r}\text { Pair } \\
\text { Comp }\end{array}$ & $\begin{array}{l}\text { wise } \\
\text { arison }\end{array}$ & $\begin{array}{l}\text { Important } \\
\text { criterion }\end{array}$ & $\begin{array}{l}\text { Designer } \\
\# 1 \text { Fuzzy } \\
\text { Estimate }\end{array}$ & $\begin{array}{c}\text { Designer } \\
\text { \#2 Fuzzy } \\
\text { Estimate }\end{array}$ & $\begin{array}{c}\text { Designer } \\
\text { \#3 Fuzzy } \\
\text { Estimate }\end{array}$ & $\begin{array}{l}\text { Aggregation } \\
\text { of } \\
\text { Designers' } \\
\text { Fuzzy } \\
\text { Estimates }\end{array}$ & $\begin{array}{c}\text { Division Of } \\
\text { Aggregated } \\
\text { Fuzzy Estimates } \\
\text { by Total Number } \\
\text { of Designers } \\
\text { Using Equation } 1\end{array}$ & $\begin{array}{c}\text { Crisp Value } \\
\text { (Defuzification } \\
\text { of Divided } \\
\text { Aggregated } \\
\text { Fuzzy Estimates } \\
\text { using Equation } \\
12 \text { ) }\end{array}$ \\
\hline 1 & MD & MH & MD & $(4,5,6)$ & $(5,6,7)$ & $(5,6,7)$ & $(14,17,20)$ & $(4.67,5.67,6.67)$ & 5.67 \\
\hline 2 & MD & LCF & MD & $(7,8,9)$ & $(8,9,9)$ & $(7,8,9)$ & $(22,25,27)$ & $(7.33,8.33,9)$ & 8.22 \\
\hline 3 & MD & SWA & MD & $(3,4,5)$ & $(2,3,4)$ & $(2,3,4)$ & $(7,10,13)$ & $(2.3,3.33,4.33)$ & 3.32 \\
\hline 4 & MD & VD & MD & $(2,3,4)$ & $(1,2,3)$ & $(2,3,4)$ & $(5,8,11)$ & $(1.67,2.67,3.67)$ & 2.67 \\
\hline 5 & MD & $\mathrm{CB}$ & MD & $(1,2,3)$ & $(2,3,4)$ & $(1,2,3)$ & $(4,7,10)$ & $(1.33,2.33,3.33)$ & 2.33 \\
\hline 6 & MD & MIV & MD & $(6,7,8)$ & $(5,6,7)$ & $(5,6,7)$ & $(16,19,22)$ & $(5.33,6.33,7.33)$ & 6.33 \\
\hline 7 & MD & $\mathrm{CF}$ & MD & $(7,8,9)$ & $(6,7,8)$ & $(6,7,8)$ & $(19,22,25)$ & $(6.33,7.33,8.33)$ & 7.33 \\
\hline 8 & MD & TPCI & MD & $(8,9,9)$ & $(7,8,9)$ & $(8,9,9)$ & $(23,26,27)$ & $(7.67,8.67,9)$ & 8.45 \\
\hline 9 & MD & WSA & MD & $(4,5,6)$ & $(3,4,5)$ & $(3,4,5)$ & $(10,13,16)$ & $(3.33,4.33,5.33)$ & 4.33 \\
\hline 10 & MH & LCF & MH & $(2,3,4)$ & $(1,2,3)$ & $(2,3,4)$ & $(5,8,11)$ & $(1.67,2.67,3.67)$ & 2.66 \\
\hline 11 & MH & SWA & MH & $(4,5,6)$ & $(5,6,7)$ & $(5,6,7)$ & $(14,17,20)$ & $(4.67,5.67,6.67)$ & 5.67 \\
\hline 12 & MH & VD & MH & $(6,7,8)$ & $(7,8,9)$ & $(6,7,8)$ & $(19,22,25)$ & $(6.33,7.33,8.33)$ & 7.33 \\
\hline 13 & MH & $\mathrm{CB}$ & MH & $(2,3,4)$ & $(1,2,3)$ & $(2,3,4)$ & $(5,8,11)$ & $(1.67,2.67,3.67)$ & 2.67 \\
\hline 14 & MH & MIV & MH & $(1,2,3)$ & $(2,3,4)$ & $(1,2,3)$ & $(4,7,10)$ & $(1.33,2.33,3.33)$ & 2.33 \\
\hline 15 & MH & $\mathrm{CF}$ & $\mathrm{CF}$ & $(7,8,9)$ & $(6,7,8)$ & $(7,8,9)$ & $(20,23,26)$ & $(6.67,7.67,8.67)$ & 7.67 \\
\hline 16 & MH & TPCI & TPCI & $(8,9,9)$ & $(7,8,9)$ & $(8,9,9)$ & $(23,26,27)$ & $(7.67,8.67,9)$ & 8.45 \\
\hline 17 & MH & WSA & MH & $(1,2,3)$ & $(2,3,4)$ & $(1,2,3)$ & $(4,7,10)$ & $(1.33,2.33,3.33)$ & 2.33 \\
\hline 18 & LCF & SWA & LCF & $(4,5,6)$ & $(3,4,5)$ & $(4,5,6)$ & $(11,14,17)$ & $(3.67,4.67,5.67)$ & 4.67 \\
\hline 19 & LCF & VD & VD & $(2,3,4)$ & $(2,3,4)$ & $(2,3,4)$ & $(6,9,12)$ & $(2,3,4)$ & 3 \\
\hline 20 & LCF & $\mathrm{CB}$ & $\mathrm{CB}$ & $(4,5,6)$ & $(3,4,5)$ & $(3,4,5)$ & $(10,13,16)$ & $(3.33,4.33,5.33)$ & 4.33 \\
\hline 21 & LCF & MIV & LCF & $(7,8,9)$ & $(7,8,9)$ & $(7,8,9)$ & $(21,24,27)$ & $(7,8,9)$ & 8 \\
\hline 22 & LCF & $\mathrm{CF}$ & LCF & $(2,3,4)$ & $(3,4,5)$ & $(2,3,4)$ & $(7,10,13)$ & $(2.33,3.33,4.33)$ & 3.33 \\
\hline 23 & LCF & TPCI & TPCI & $(4,5,6)$ & $(5,6,7)$ & $(5,6,7)$ & $(14,17,20)$ & $(4.67,5.67,6.67)$ & 5.67 \\
\hline 24 & LCF & WSA & LCF & $(6,7,8)$ & $(7,8,9)$ & $(6,7,8)$ & $(19,22,25)$ & $(6.33,7.33,8.33)$ & 7.33 \\
\hline 25 & SWA & VD & SWA & $(3,4,5)$ & $(2,3,4)$ & $(2,3,4)$ & $(7,10,13)$ & $(2.33,3.33,4.33)$ & 3.33 \\
\hline 26 & SWA & $\mathrm{CB}$ & $\mathrm{CB}$ & $(1,2,3)$ & $(2,3,4)$ & $(1,2,3)$ & $(4,7,10)$ & $(1.33,2.33,3.33)$ & 2.33 \\
\hline 27 & SWA & MIV & SWA & $(5,6,7)$ & $(6,7,8)$ & $(5,6,7)$ & $(16,19,22)$ & $(5.33,6.33,7.33)$ & 6.33 \\
\hline 28 & SWA & $\mathrm{CF}$ & SWA & $(7,8,9)$ & $(8,9,9)$ & $(8,9,9)$ & $(23,26,27)$ & $(7.67,8.67,9)$ & 8.45 \\
\hline 29 & SWA & TPCI & TPCI & $(8,9,9)$ & $(7,8,9)$ & $(7,8,9)$ & $(22,25,27)$ & $(7.33,8.33,9)$ & 8.22 \\
\hline 30 & SWA & WSA & SWA & $(3,4,5)$ & $(2,3,4)$ & $(2,3,4)$ & $(7,10,13)$ & $(2.33,3.33,4.33)$ & 3.33 \\
\hline 31 & VD & $\mathrm{CB}$ & VD & $(2,3,4)$ & $(3,4,5)$ & $(3,4,5)$ & $(8,11,14)$ & $(2.67,3.67,4.67)$ & 3.67 \\
\hline 32 & VD & MIV & VD & $(6,7,8)$ & $(5,6,7)$ & $(6,7,8)$ & $(17,20,23)$ & $(5.66,6.67,7.67)$ & 6.33 \\
\hline 33 & VD & $\mathrm{CF}$ & $\mathrm{CF}$ & $(7,8,9)$ & $(8,9,9)$ & $(7,8,9)$ & $(22,25,27)$ & $(7.33,8.33,9)$ & 8.22 \\
\hline 34 & VD & TPCI & TPCI & $(3,4,5)$ & $(2,3,4)$ & $(2,3,4)$ & $(7,10,13)$ & $(2.33,3.33,4.33)$ & 3.33 \\
\hline 35 & VD & WSA & VD & $(2,3,4)$ & $(3,4,5)$ & $(3,4,5)$ & $(8,11,14)$ & $(2.67,3.67,4.67)$ & 3.67 \\
\hline 36 & $\mathrm{CB}$ & MIV & $\mathrm{CB}$ & $(6,7,8)$ & $(7,8,9)$ & $(6,7,8)$ & $(19,22,25)$ & $(6.33,7.33,8.33)$ & 7.33 \\
\hline 37 & $\mathrm{CB}$ & $\mathrm{CF}$ & $\mathrm{CB}$ & $(4,5,6)$ & $(3,4,5)$ & $(4,5,6)$ & $(11,14,17)$ & $(3.67,4.67,5.67)$ & 4.67 \\
\hline 38 & $\mathrm{CB}$ & TPCI & TPCI & $(7,8,9)$ & $(6,7,8)$ & $(7,8,9)$ & $(20,23,26)$ & $(6.67,7.67,8.67)$ & 7.67 \\
\hline 39 & $\mathrm{CB}$ & WSA & $\mathrm{CB}$ & $(8,9,9)$ & $(7,8,9)$ & $(7,8,9)$ & $(22,25,27)$ & $(7.33,8.33,9)$ & 8.22 \\
\hline 40 & MIV & $\mathrm{CF}$ & MIV & $(1,2,3)$ & $(2,3,4)$ & $(2,3,4)$ & $(5,8,11)$ & $(1.67,2.67,3.67)$ & 2.67 \\
\hline 41 & MIV & TPCI & MIV & $(4,5,6)$ & $(3,4,5)$ & $(4,5,6)$ & $(11,14,17)$ & $(3.67,4.67,5.67)$ & 4.67 \\
\hline 42 & MIV & WSA & WSA & $(5,6,7)$ & $(4,5,6)$ & $(4,5,6)$ & $(13,16,19)$ & $(4.33,5.33,6.33)$ & 5.33 \\
\hline 43 & $\mathrm{CF}$ & TPCI & $\mathrm{CF}$ & $(3,4,5)$ & $(2,3,4)$ & $(3,4,5)$ & $(8,11,14)$ & $(2.67,3.67,4.67)$ & 3.67 \\
\hline 44 & $\mathrm{CF}$ & WSA & $\mathrm{CF}$ & $(6,7,8)$ & $(5,6,7)$ & $(6,7,8)$ & $(17,20,23)$ & $(5.67,6.67,7.67)$ & 6.67 \\
\hline 45 & TPCI & WSA & TPCI & $(5,6,7)$ & $(6,7,8)$ & $(5,6,7)$ & $(16,19,22)$ & $(5.33,6.33,7.33)$ & 6.33 \\
\hline
\end{tabular}

Table A1 Pairwise Comparison of Ship Hydrostatic Parameters/Criteria under Uncertain in Fuzzy Environment 
Table A2 Ship Hydrostatic Parameters/Criteria Crisp Value Matrix

\begin{tabular}{ccccccccccc}
\hline CRITERIA & MD & MH & LCF & SWA & VD & CB & MIV & CF & TPCI & WSA \\
\hline MD & 1 & 5.67 & 8.22 & 3.32 & 2.67 & 2.33 & 6.33 & 7.33 & 8.45 & 4.33 \\
MH & $1 / 5.67$ & 1 & 2.67 & 5.67 & 7.33 & 2.67 & 2.33 & $1 / 7.67$ & $1 / 8.45$ & 2.32 \\
LCF & $1 / 8.22$ & $1 / 2.67$ & 1 & 4.67 & $1 / 3$ & $1 / 4.33$ & 8 & 3.33 & $1 / 5.67$ & 7.33 \\
SWA & $1 / 3.32$ & $1 / 5.67$ & $1 / 4.67$ & 1 & 3.33 & $1 / 2.33$ & 6.33 & 8.45 & $1 / 8.22$ & 3.33 \\
VD & $1 / 2.67$ & $1 / 7.33$ & 3 & $1 / 3.33$ & 1 & 3.67 & 6.33 & $1 / 8.22$ & $1 / 3.33$ & 3.67 \\
CB & $1 / 2.32$ & $1 / 2.67$ & 4.33 & 2.33 & $1 / 3.67$ & 1 & 7.33 & 4.67 & $1 / 7.67$ & 8.22 \\
MIV & $1 / 6.33$ & $1 / 2.33$ & $1 / 8$ & $1 / 6.33$ & $1 / 6.33$ & $1 / 7.33$ & 1 & 2.67 & 4.67 & $1 / 5.33$ \\
CF & $1 / 7.33$ & 7.67 & $1 / 3.33$ & $1 / 8.45$ & 8.22 & $1 / 4.67$ & $1 / 2.67$ & 1 & 3.67 & 6.67 \\
TPCI & $1 / 8.45$ & 8.45 & 5.67 & 8.22 & 3.33 & 7.67 & $1 / 4.67$ & $1 / 3.67$ & 1 & 6.33 \\
WSA & $1 / 4.33$ & $1 / 2.32$ & $1 / 7.33$ & $1 / 3.33$ & $1 / 3.67$ & $1 / 8.22$ & 5.33 & $1 / 6.67$ & $1 / 6.33$ & 1 \\
Sum & 3.05 & 24.712 & 25.67 & 26.116 & 26.892 & 18.461 & 43.569 & 28.124 & 18.124 & 43.308 \\
\hline
\end{tabular}

